\title{
An Irreproachable Dogmatics? Plotinus, Theodore Metochites and the Sixth Chapter of the Letter On Education
}

\author{
Dmitry I. Makarov \\ The Urals State M.P. Mussorgsky Conservatoire, Yekaterinburg, Russia; \\ The National Research University Higher School of Economics (HSE), \\ Perm, Russia \\ dimitri.makarov@mail.ru
}

\begin{abstract}
In the chapters 6 to 9 of his On Education (ca.1305) Theodore Metochites (ca.1270-1332) expounded his understanding of the fundamentals of Orthodox dogmatics. Basing his Triadological views on Plotinus, he went so far as to dissociate the divine essence from the Persons. By additionally exalting God the Father as the Keeper of Providence over all the beings and God the Son as the Redeemer, our thinker assigned to the Holy Spirit only a subsidiary role in the Economy of our salvation perforce. So, it was his deliberate choice not to say even a word concerning Filioque, the psychological trauma ensuing from his father's death being not the only reason for this omission (in addition to what Ihor Ševčenko thought). In Christology Theodore moved away from John of Damascus' teaching on the immaculate passions of Jesus Christ's humanity taken in its postlaparian state, but then he repeatedly quoted Gregory of Nazianzus. In doing so Metochites might have thought that Gregory had terminated "the Golden Age" of patristics. I have identified an important quote from Gregory which remained unnoticed by the editor.
\end{abstract}

\section{Keywords}

Theodoros Metochites - On Education - dogmatics - Triadology - Christology Gregory the Theologian - John of Damascus - conservatism 
Theodore Metochites ( $c a .1270-1332)$ wrote his 1oth Logos, or treatise, On Education about $1305 .{ }^{2}$ According to John Polemis the author exposes very distinctly the tenets of Orthodox faith. ${ }^{3}$ However, the point is questionable. It is Börje Bydén, who came to realize in 2003 that our Byzantine thinker "goes on to state in rather less exacting terms (italics supplied D. M.) that even in more peripheral matters one would do best to take the Church Fathers at their word". We would like to make a following step by trying to specify the "less exacting" character of the terms in question. This will bring us to a deeper understanding of the triadological and Christological conceptions involved.

The complete sixth Chapter of the On Education occupies pp. 22.8-28.13

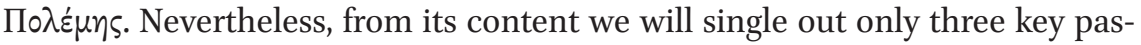
sages in original Greek and in our English translation. We adduce the passages below.

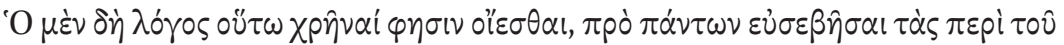

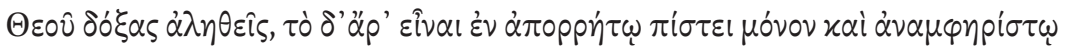

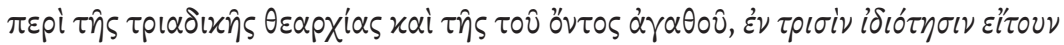

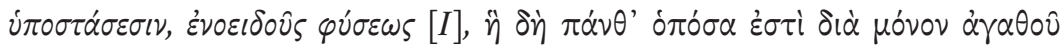

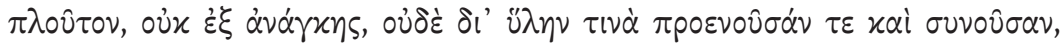

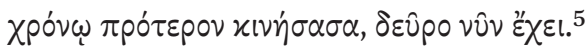

1 The present study is a part of a larger project $\mathrm{Nr}$ 16-18-10202, History of the Logical and Philosophical Ideas in Byzantine Philosophy and Theology, implemented with a financial support of the Russian Science Foundation.

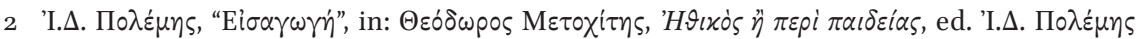

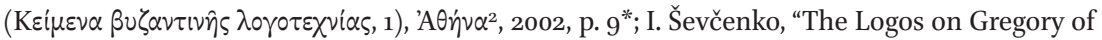
Nazianzus by Theodore Metochites", in: Geschichte und Kultur der Palaiolohgenzeit. Referate des Internationalen Symposions zu Ehren von Herbert Hunger (Wien, 3o. November bis 3. Dezember 1994), ed. W. Seibt (Österreichische Akademie der Wissenschaften, Philosophischhistorische Klasse, Denkschriften, Bd. 241; Veröffetntlichungen der Kommission für Byzantinistik, Bd. viII), Wien, 1996, pp. 221-233, here p. 223.

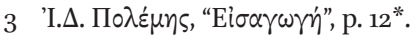

4 B. Bydén, Theodore Metochites' Stoicheiosis astronomike and the Study of Natural Philosophy and Mathematics in Early Palaiologan Byzantium (Studia Graeca et Latina Gothoburgensia, LXVI), Göteborg, 2003, pp. 272-277, here p. 273.

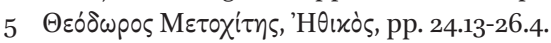


Therefore, the word determines the way of our thinking in the following manner. Firstly, one ought to acquire the true and Orthodox opinions about God, i.e. to stay solely in an ineffable and incontestable faith in the Triadic Godhead and the true Good, in the three attributes (or 'distinctive properties'. D. M.), or hypostases, of the nature having the form of unity $[I]$, which earlier in time set in motion and still upholds everything there is $(J n .5,17)$ not out of necessity or through the agency of a kind of a preexisting or coexisting matter, but only due to the abundance of its goodness. ${ }^{6}$

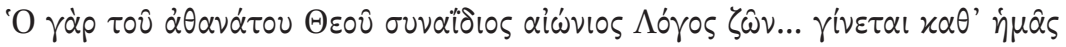

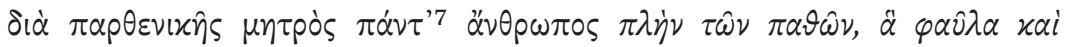

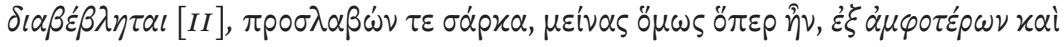

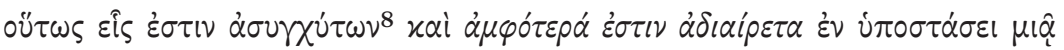
$[I I I] \cdot{ }^{9}$

6 Throughout all this reasoning the common nature of the Trinity, having the form of unity, is mounted over the Persons, as if it had assumed properties and functions of a fourth hypostasis which would be the most supreme one in the Godhead. Such a theological framework is similar to neo-Arian doctrines. Glaring is the fact that Metochites, too, confused the principles of nature and hypostasis. Unlike Gregory of Cyprus, he must have appropriated insufficiently the classical Cappadocian, Alexandrian and Maximian heritage (together with the ideas of Pseudo-Areopagite). This holds true in particular for the famous notion of hypostasis in St. Basil the Great. J.-C. Larchet stressed its importance for St. Maximus the Confessor: J.-C. Larchet, La divinisation de l'homme selon St. Maxime le Confesseur, Paris, 1996, p. 678. Let us make a step further. To all appearances, Theodore regarded the three Persons of the Trinity as three "Forms", which at least partly brings his Triadology closer to the analogous doctrines of George Acropolites (13th century) and the similar-minded persons. However, unlike John Philoponus' Tritheism, Metochites' theological sketches represented the common substance of God as something real and even super-real (in the Byzantine meaning of $\dot{\tau} \pi \varepsilon p-)$. Nevertheless, it remains unclear whether the Grand Logothete understood his "Forms" as singular and individual essences. Scholars should look for further analogies. However, even now, we may suggest that Theodore somehow "antedated" Gregory of Cyprus in what Triadology is concerned, and his views upon the subject approached hazardously to those of neo-pagans, on one side, and to the doctrines of radical neo-scholastics, like John Veccus, on another side. It is remarkable that he teaches nowhere about the Divine energy/ energies. See Ch. Savvatos,

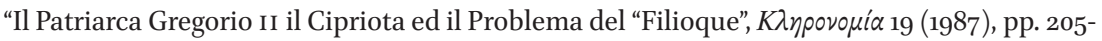
218; D. Makarov, "The Holy Spirit as Life and Energy. The Treatment of Athanasius' Ad Serapionem I, 20-21 in the Late Thirteenth Century and Its Implications for the Hesychast Controversy", Byzantion 80 (2010), pp. 197-246; etc.

$7 \Pi \alpha \dot{v} \tau$ - is an abridgment from $\pi \dot{\alpha} \nu \tau \omega \varsigma$.

8 One could expect here an important addition "and in the two unconfused natures", which would serve as a fence from the classical Monophysite Christology here and which is lacking in Metochites. Cf.: P. Piret, "Christologie et théologie trinitaire chez Maxime le Confesseur, d'après sa formule des natures "desquelles, en lesquelles et lesquelles est le Christ", in:Maximus Confessor. Actes du Symposium sur Maxime le Confesseur (Fribourg, 2-5 septembre 1980), eds. F. Heinzer, Ch. Schönborn (Paradosis, 27), Fribourg, 1982, pp. 215-222.

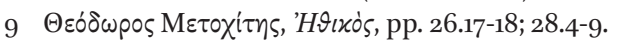


For the coeternal and living Word without beginning of God Immortal... has become the same complete man with us, being born from the virginal Mother, save for the passions, which He threw away as blameworthy [or 'bad'. D. M.] [II]. Having assumed the flesh, He remained, nevertheless, what He had been, ${ }^{10}$ and thus He is the One from the both unconfused [constituent parts], and the both $^{11}$ are indivisible in the one and unique hypostasis [III].

Let us now provide these fragments with a short theological and philosophical commentary.

A Commentary to the Passage I

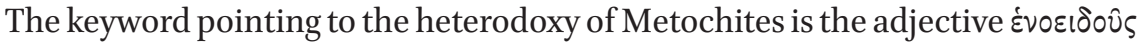

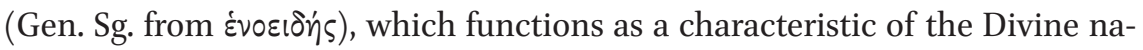
ture in fragm. I. We may say with certainty that the term made its way to Theodore's text from Plotinus' Enn. vi.9.5. Indeed, we read there that mind is to be thought of as a unity of the multiple (the logoi of the beings) and the one (that is, the vov̂s properly). These two poles form the intelligible cosmos. ${ }^{12}$ However, there is a unity above the Mind, and this is that of having the form of unity (oin

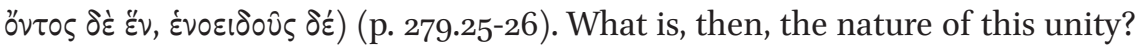
The entity in question is the Source of all the beings; it is the power, which engenders beings, while at the same time remaining within itself; "therefore, it does not decrease, even when it stays in those beings which were created by it

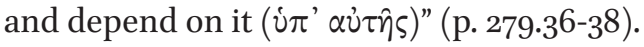

The operations of the Divine nature in Metochites look very much like the acts of this nature of the One, united with its power, in Plotinus. It is presumably for this reason that our thinker does not include into his text the discourse of the Divine energies. Neither does he mention the role of the Holy Spirit as the Giver of the charismas of the Trinity to the righteous.

It may occur that this chapter VI.9.5 was Metochites' main source when he was composing his sixth chapter of On Education. In vi.9.6 we read that (in accordance with Theodore's own view), the One is infinite not because of

10 This is an almost verbatim quotation from St. Gregory the Theologian, cf.: "O $\mu \dot{\varepsilon} \nu \hat{\eta} \nu$,

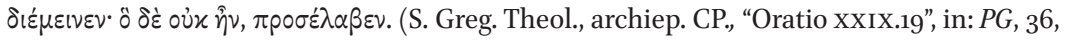
col. 100A. (34)).

11 These are evidently Christ's divinity and His flesh. It is typical of Metochites that he does not insert into this essential fragment of his personal creed the term "nature" (or "essence"). One concludes that our author did not succeed in conceptualizing the interrelationship between hypostasis and essence as seriously as it was worthwhile. Hereinafter I will quote some passages from this edition in the main text, giving in brackets the number(s) of page(s) and line(s). 
its magnitude but due to "the immensity ( $\tau \hat{\omega} \dot{\alpha} \pi \varepsilon \rho \lambda \dot{\eta} \pi \tau \omega)$ of its power" (p. 280.11-12). The One is bigger than the Mind or God (p. 280.12-13), or thinking (p. 280.13-15), it is the most all-sufficient entity from that which exists (p. 280.16$18 ; 280.24-281.26$ ). It is the unity as such, the supreme unity (p. 280.20), which needs no containing one (p. 281.30). On the contrary, all the beings are established by it, and each one of them is contained in its properly allotted place

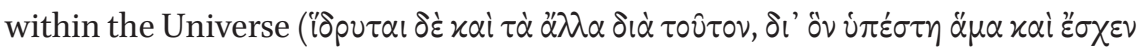

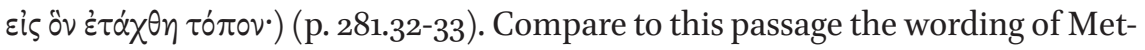

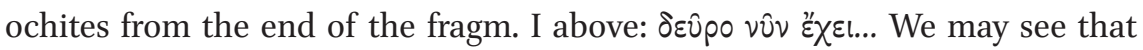

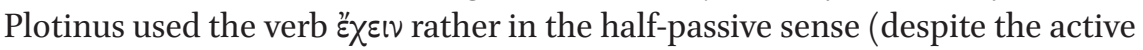
voice). He applied the verb to the certain beings each one of which upholds itself in the being as such with the power of the One, whereas in Metochites $\varepsilon^{\prime \prime} \chi \varepsilon \varepsilon \nu$ describes the analogous operation of the Divine nature. I think that in this case, too, Plotinus was the immediate source of Theodore.

\section{$4 \quad$ Why Did Metochites Say Nothing about the Filioque? A Hypothesis}

In his declarations, Metochites was keen towards the problem of Orthodoxy and heresy. Thus, in his 13th treatise A Refutation of the Ignorant Scholars he stressed the importance of delving into Plato's and Aristotle's theories of nature, ${ }^{13}$ but at the same time pointed out that a number of tenets of both must be discarded as opposing to the Truth, ${ }^{14}$ that is to say, to the dogmas of "our Christian piety ( $\tau \hat{\jmath} \varsigma$... $\theta \varepsilon \circ \sigma \varepsilon \beta \varepsilon i \alpha \varsigma) » .{ }^{15}$ Actually, he was not so punctual in following this principle.

Indeed, why did Theodore say almost nothing about the Filioque ${ }^{16}$ A snatch from his early Third treatise, dating to the gos of the thirteenth century, shows that the young thinker used to repeat the Orthodox formulation about the Spirit's procession from the Father without entering into further discussions. ${ }^{17}$ A closer look to the Ch. 6 of the On Education will help us in correcting this conclusion. In Theodore's thought, the common essence of Godhead, together with God the Father, prevailed as two supreme Beginnings. (Consequently, in his sketch of Christian Weltanschauung pneumatology could not

\footnotetext{
13 Ch. 5: I. Ševčenko, Études sur la polémique entre Théodore Métochite et Nicéphore Choumnos (Corpus Bruxellense Historiae Byzantinae; Subsidia, III), Bruxelles, 1962, pp. 188-217; here p. 193.5.1-11.

14 Ševčenko, Études, p. 193.5.13.

15 Ševčenko, Études, p. 193.5.12.

16 Cf.: Bydén, Theodore Metochites' Stoicheiosis astronomike, p. 274.

17 See Vindob. Philol. Gr. 95, f. 34v; Bydén, Theodore Metochites' Stoicheiosis astronomike, p. 276, n. 30 .
} 
be put in the first place - it was among the secondary subjects.) It was quite natural, besides, that after the tragic decease of his father Georges, Theodore was extremely unwilling to come to grips with the procession of the Spirit.

However, what was his goal in this adumbrating some basic outlines of the Christian doctrine in the sixth chapter? He must have had a cognitive interest in clearing up this range of problems. Nevertheless, any attempt to conceptualize this or that part of theological agenda was absorbed by his stable and systematic predilection towards ancient philosophy. The wisdom of the ancient Greeks just provided Theodore with the lines of reasoning essential in the field of Triadology.

\section{5}

\section{A Commentary to the Passages II and III}

It remains unclear in the fragm. II whether God the Word has assumed into His hypostasis the blameless passions or not. Therefore, Theodore's position jeopardizes Orthodox Christology by coming too far in the direction of Honorius' Monotheletism.

Theodore's short phrase $\tilde{\alpha} \varphi \alpha \hat{\nu} \lambda \alpha$ xai $\delta \alpha \beta \hat{\varepsilon} \beta \lambda \eta \tau \alpha \iota$ comes at odds with, say, St. Theodore the Studite's deliberations upon the same theme. Alexis Torrance has recently expounded Theodore's views as follows: “...Theodore's philosophical commitments emergent from his iconology do not allow for the existence of an 'unfallen human nature' that Christ can assume, since human nature only exists through individual instantiation, and all individual human beings from Adam on are post-lapsarian (namely, corrupt and prone to sin)". ${ }^{18}$ Actually, if one wishes to clear up the point so presumably misconstrued by Metochites, one will have to read the beginning of Damascene's Exact Exposition... III, 20 (ch. 64):

We confess that Jesus Christ has assumed all natural and blameworthy $(\dot{\alpha} \delta \dot{\alpha} \alpha \lambda \eta \tau \tau)$ human passions. For He has assumed all the man and all the things human, save for $\sin . . .{ }^{19}$

Most likely, Metochites felt certain hostility towards highbrow theology, and this would account for his ignorance of this Damascene's passage when writ-

18 A. Torrance, “'Assuming our nature corrupted by sin": Revisiting Theodore the Studite on the Humanity of Christ", in: SP 96, ed. M. Vinzent, Leuven-Paris-Bristol, CT, 2017, pp. 451$45^{6}$, here p. $45^{6}$.

19 Die Schriften des Johannes von Damaskos, Bd. II. Expositio fidei, ed. P.B. Kotter, O.S.B. (PTs, 12), Berlin-New York, 1973, p. 162.2-4. 
ing the sixth chapter of his text. He might well have thought that 'the golden age of the Fathers' was over very long ago, immediately after the decease of St. Gregory the Theologian. Had our writer lived in the eleventh century, he would have had all the chances to align with the adversaries of St. Symeon the New Theologian. ${ }^{20}$

What is glaring in the fragment III is the lack of the most essential term "nature", or "essence", in the formula. It seems to me that the interrelationship between hypostasis and nature was not conceived and conceptualized by Metochites with due acumen. Be this as it may, the neutral gender $\alpha \mu \varphi o ́ \tau \varepsilon p \alpha$ makes one suspect a sub-/conscious orientation to the theological language of St. Gregory the Theologian here, to quote only the famous lines from the Ep. 101, To Cledonius: "To put it briefly: these what the Savior consists of are $\alpha \lambda_{0}$ xai

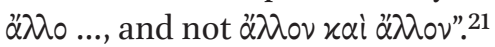

Thus, we discern in Metochites the same tendency to orient himself towards the pre-Chalcedonian theological language of St. Gregory the Theologian. This may account for his lack of addition "in the two natures" to the "out of the two natures [that is, divinity and humanity in Christ]". It would mean that in Christology our Byzantine thinker turns out to "pre-date" not only Gregory of Cyprus, but even St. Maximus the Confessor. Such a conservative stance in theology is not so far from Acindynus' conservatism and even aggravates it more. Acindynus, for his part, quoted St. Maximus and Planudes' translation of Augustine's De Trinitate. ${ }^{22}$ The last patristic author whom he quoted was Photius. ${ }^{23}$ Obviously, his quoting on the part of Metochites was completely out of question for a number of theological and psychological reasons.

Nevertheless, if we look at Metochites from another viewpoint, we will see that this very person, who produced a sketch of a rather archaic theological system, was a harbinger of the new, and more secularized, philosophy of the Renaissance - together with Pachymeres, Gregoras and their associates. ${ }^{24}$

20 Cf. our short remarks: Д.И. Макаров, “Федор Метохит о двух видах созерцания», in: Византийский мир: реалии и интерпретащии, под ред. Т.В. Кущ, Екатеринбург, 2018, cc. 35 -37.

21 Grégoire de Nazianze, Lettres théologiques, ed. P. Gallay (SC, 208), Paris, 1974, p. 44.20.

22 Cf.: D. Moschos, "Reasons of Being versus Uncreated Energies - Neoplatonism and Mathematics as Means of Participating in God according to Nicephorus Gregoras", in: SP 96, ed. M. Vinzent, pp. 547-554, here p. 551.

23 See D. Makarov, "Some problems of the theology of the Divine Light in the mystical treatise of Theophanes of Nicaea", in: Proceedings of the 21st International Congress of Byzantine Studies (London, 21-26 August 2006), Vol. III, Abstracts of Communications, eds. F.K. Haarer, E. Jeffreys, J. Gilliland, Aldershot, 2006, pp. 229-230, esp. p. 229. 